\title{
The Analysis of Space Semiotic in Colonial Building Area Depok
}

\begin{abstract}
Azkia Rostiani Rahman
University of Indonesia

Abstract: The colonial building area as part of the history of the Indonesian nation, especially the colonial building area in Depok becomes interesting to be discussed. Based on some sources from online media mentioned that the colonial building area in Depok received less public and government attention as part of the cultural heritage. Instead, it appears the myths about the area of the Colonial building as mystical places such as Panus Bridge and Landlord Land Cimanggis considered as a mysterious building. Space in buildings, other than as a protector against external harm, can also be something that shows one's identity (Hoed, 2014: 132). Therefore, the study of space is very interesting. How individuals, societies, and societies have distinct meanings about space itself. How they then see the same signs but have different perceptions about space. The aim of this research is to know how space (colonial building area) is characterized by Depok society and to know how individuals and communities give meaning to the colonial building in Depok. This research used macrosemiotic analysis approach by Danesi and Perron as a step analysis. In order to analyze the data, researcher used Peirce Tricotomy Perspective and Danesi and Peron perspective i.e. denotation, connotation, and annotation.
\end{abstract}

Keywords: Colonial building, Depok, Trikotomy Peirce, Danesi and peron

\section{Introduction}

Colonial building area is a historic place in Depok, one of city in West Java. There are some colonial period buildings that are still standing upright: the Panus Bridge that crosses the Ciliwung River and connects the Old Depok and Depok II, Immanuel Church on Jalan Pemuda, Pondok Cina on Jalan Margonda which is now the ornament of Margo City, and the former Landlord's house Cimanggis (km 34 road towards Bogor).

In Danesi (1999), it is said that the building is a sign of identity, status, power, and etc. Mosques, churches, temples, temples are built so that its adherents can celebrate and live what they believe and adhere to in accordance with their respective beliefs. Fortress and castle are designed for defense purposes. Castles, villas, and skyscrapers were built to display wealth and power. In essence, architectural practices reflect the organization and social lifestyle. The buildings were built not only for residence, but also enable us to understand social construction.

According to Benny Hoed (2014), every human being sees space in the same way; something that is an extension of itself or what is called by Danesi as the extension of self. Man then gives meaning to the spaces in his life by using his semiotic ability. Humans provide functions to certain spaces.

The colonial building area as part of history of Indonesian nation, especially the colonial building in Depok becomes interesting then to be discussed. Based on several sources from the online media, it was mentioned that the colonial building area in Depok received less public and government attention as part of the cultural heritage. Instead it appears the myths about the area of the Colonial building as mystical places such as Panus Bridge and Landlord House Cimanggis considered the mysterious building especially in the Bridge Panus there was ever shooting program 'Another World,' which is a series of reality events with the theme of the supernatural at the station Trans TV. One segment in the 'Other World' is a Grief Test where one of the contestants will be left alone somewhere (usually a haunted place) from night until sunrise. As one of the respondents said that since the 
Bridge Panus is considered more mystical and creepy. But it is also interesting to see the opinions of the surrounding community who live around the Bridge and the House that they do not feel any element of mystical in the bridge. They used to pass everyday and move as usual around there though night, but did not find the element of its mystical. Unlike the Panus Bridge and the Cimanggis Landlord, Chinese Cottage, as a Chinese ethnic marker, on the compass website written by Bayu Galih, it is said that if it refers to its name, that is China's cottage, it has lost its historical and cultural context. While GPIB Immanuel Depok as one of the colonial-style buildings that are still up to now, is clarified as something common to the surrounding community.

Space in buildings, instead of protector against external harm, can also be something that shows one's identity (Hoed, 2014: 132). Based on what was said before, the study of space is very interesting to study. How individuals, societies, and societies have their own meanings of space. How they then see the same signs but have different perceptions about space. It attracted the attention of researchers to study about the colonial building in Depok.

\subsection{Problem}

Based on the background above, there are two problems in this research, i.e.

1. How space (colonial building area) is marked by Depok society?

2. How individuals and communities give meaning to the colonial building in Depok?

\subsection{Aim}

The purpose of this research is to:

1. Know how space (colonial building area) is characterized by Depok society.

2. Know how individuals and communities give meaning to the colonial building in Depok.

\section{Theoretical Background}

\section{Peirce Trikotomy}

Charles Sanders Peirce (1839-1914) is one of the semiotic figures who introduced the pragmatic semiotics. According to Weiss and Burk in Noth (1995, p.39), he is one of the founders of the theory of modern (semiotic) sign. According to Peirce, the sign and its meanings are not structures, but a cognitive process called Semiosis. Hoed $(2014$, p. 8) defines semiosis as a process of meaning and interpretation of signs. This semiotic process passes through three stages: first, the perception of representamen sign (through the five senses), secondly, spontaneously associates the representation with experience in the human cognition that represents the representation (called the object), and the last one is interpreting the object according to its desires (interpretant). Thus, semiosis is the process of forming a sign that departs from representamen who is spontaneously related to the object in human cognition and then given a certain interpretation by human being as interpretant (Hoed, 2014. p.9).

The Semiotic Paradigm by Peirce is famous for its trichotomy, Representament $\square$ Objects $\square$ Interpretive that is interconnected which cannot be separated. Peirce trichotomy is often described in the form of a 'triangle' diagram. According to Christomy, an important part of the Peirce trichotomy is that there is an explanation of the function of each element that builds the mark intact. Therefore, signs involve (R), (O), and (I). (R) as Reprsentamen represents (O) in three ways: icon (similarity), index (Appointment or causality), and Symbol (convention or agreement). Representamen that refer to objects in different ways then trigger the process of interpretation (I). The process of interpretation is interpreted in three ways namely qualisign (something potential), sinsign (proposition) and legisign (argument).

In Noth (1995, p.45), there are ten (10) classifications of sign that related to Peirce trichotomy i.e.

1. (Rhematic Iconic) Qualisign is a sign related to quality. 
2. (Rhematic) Iconic Sinsign is a sign that shows resemblance to its object. Examples in this category are paintings, maps, drawings, tables, diagrams, and more.

3. Rhematic indexical sinsign is a sign based on direct practice, where the mark appears due to something.

4. Dicent (Indexical) sinsign is a sign that gives information about something. such as the direction of the wind.

5. Iconic Legisign is a sign that informs the norm or the law.

6. Rhematic Indexical Legisign is a sign that refers to a particular object. For example pronouns instructions ..

7. Dicent Indexical Legisign is a sign of meaningful information and points to the subject of information. Forexample a traveling salesman who shouted his food to sell.

8. Rhematic Symbolic (legisign) is a sign associated with an object through a general idea association. For example, like common noun.

9. Dicent symbolic (legisign) is a sign connected to an object through associations in the brain. For example when in class the students are noisy, and suddenly the teacher says "silent!" Or "pay attention!"

10. Argument (Symbolic Legisign) is a sign that a person gives to something for some reason.

\subsection{Denotation, Connotation, and Annotation}

In Semiotics, concepts are classified according to the pattern of meaning. According to Danesi (1999: 80), there are three types of patterns: denotation, connotation, and annotation. Denotation is the conceptual meaning between signifier and signified. For example the word cat does not refer to certain types of cats, but it is a category of animals that we know to have the character 'like a cat.' Connotation is a way of labeling operative in production level and text interpretation like poetry, novel, musical composition, art / culture as cultural products. And Annotation is the meaning of a concept arising from personal interpretation and subjective feeling.

\subsection{Space}

Discussing about space, we also need to talk about the concept of proxem and proxemics. According to Danesi (1999) Proksem is the smallest unit of space between individuals with other individuals, or also the smallest unit of body orientation. While proxemics is a Semiotic branch that studies the structure of the marking between the physical space one maintains in a social context. An example of how we can see space as something that is understood by society is the inauguration ceremony to be a professor. In the ceremony, a pedel (people who brings a stick and walk in front of the professor) with a command stance leads the way of ceremonial. Pedel, even though his daily position is lower than the rector, but the rector and the board of professors are subject to the pedel. In the procession, a pedel stood at the front and then followed by the rector and followed by professor. The division of space is very clear between the rector's seats and the board of professors, the professors who are confirmed and the seat of the audience.

According to Benny Hoed (2014), Every human being sees space in the same way; that is an extension of itself or what is called Danesi as the extension of self. Man then gives meaning to the spaces in his life by using his semiotic ability. Humans provide functions to certain spaces. Inside Hoed also, Semiotic distinguish space into two namely the physical space (space) and semiotic space (Place).

Danesi and Perron (1999) in Benny Hoed (2014), provides a way of analyzing space as the object of research from three perspectives, namely 'territoriality', 'extension of self', and meaning or 'social connotation' (coded connotation). Space as a symptom of territoriality means that we see space as an objective physical body. The meaning of these spaces is referred to as the social connotation (coded connotation); namely the meaning given by the community which the meaning is already known by the citizens.

According to Danesi (2011), the Space Code is divided into three main categories i.e. public space, private space, and sacred space. Public spaces govern the way people interact in public places. The private spaces 
govern the ways of interacting in the private realm, and the sacred space governs interactions in places that are said to have metaphysical, mystical, and spiritual qualities. Space code allows us to interact in the community in accordance with the codes that have been mutually agreed upon.

In Danesi (1999), it is said that the building is a sign of identity, status, power, and so on. Mosques, Churches, temples, temples are built so that its adherents can celebrate and live what they believe and adhere to in accordance with their respective beliefs. Fortress and castle are designed for defense purposes. Castles, villas, and skyscrapers were built to display wealth and power. In essence, architectural practices reflect the organization and social lifestyle. The buildings built not only for residence, but also enable us to understand social construction.

\subsection{Colonial Former Regions in Depok}

Colonial building area is a historic place in the city of Depok. There are some colonial period buildings that are still standing upright: the Panus Bridge that crosses the Ciliwung River and connects the Old Depok and New Depok, Immanuel Church on Pemuda street, Pondok Cina on Margonda street which is now the ornament of Margo City, and the former Landlord's house Cimanggis (km 34 road towards Bogor).

\section{Panus Bridge}

Panus Bridge is a bridge connecting Old Depok and New Depok which was built in 1917 until 1918 when the VOC was still in power. Panus name taken from the name of the person who designed the architect that is Stefanus Leander. The bridge, which has a length of $100 \mathrm{~m}$ and a width of $5 \mathrm{~m}$, was used as a connecting lane up to 1990. Now, a Panus II bridge has been built adjacent to the previous Panus Bridge. The new bridge was built due to the need for greater access since vehicles are increasing, yet the Panus bridge (formerly) are less large so that sometimes cause congestion.

\section{GPIB (Immanuel Depok Church)}

In an article edited by Desy Afrianti on the Autonomy website it is said that Immanuel Depok Church is a simple old church built since the Dutch residence in Indonesia. In those days around the 1600s, the slavery system still prevailed, and many slaves came from Ambon, Sulawesi, Bugis, Borneo, and Bali. In short, Cornelis then freed the slaves who worked on his estate after baptizing 200 slaves of 12 families. The names of the twelve baptized families were engraved on the doors of GPIB church Immanuel Depok inaugurated by Chastelein. The names are Soedira, Loen, Bacas, Isaac, Leander, Laurens, Jonathans, Tholense, Samuel, Joseph, Jakob and Zadokh. These twelve families are also known as 'Dutch Depok'. After Cornelis Chastelein died, he granted his land for the twelve families to process. After Indonesia became independent, Chastelein's Depok land was bought by the Indonesian government. Of the land purchased, the remaining is Immanuel Church of Depok, school, rectory, meeting hall and burial area of 0.8621 hectares. All of these Chastelein relics are still managed by 12 families that were liberated Chastelein. They then established Chornelis Chastelein Institute (LCC) to administer and process Chastelein's assets to date.

\section{Pondok China (Chinese Hut)}

According to Alwi Shabab, Chinese cottage was originally formed by Chinese traders who trade in Depok. Previously Depok land which is a private land, owned by Cornelis Chastelein (one of the VOC officials) is inherited to 12 descendants of Cornelis itself. one of the contents of the testament is that Chinese traders are prohibited from building around Depok, eventually the Chinese traders took the initiative to stay in a village on the edge of the city of Depok in the direction of Jakarta. That is what became the fore runner of Chinese Cottage. As for another version of the naming of China Cottage, quoted from website otonomi.com that there used to be a group of ethnic Chinese who occupy a small part of the forest of Bojong Village. They set up a cottage, from the hut that is the name of this Chinese cottage. Until now, there are several other relics of ethnic Chinese in the area of Chinese cottage which is Chinese cemetery and a house of Chinese architecture. But ethnic Chinese footsteps are hard to find because there are many new buildings around it. China Hut area is now exactly the 
towering Margo City building. The house that characterizes the Chinese Cottage is currently inside the Margo City Building area.

\section{Cimanggis Landlord House}

According to Arwan Amin in his personal blog, Cimanggis Landlord House, is one of the historic places mentioned in the book written Adolf Heukeun with the title 'Historic Places'. The house has a distance of about 1 $\mathrm{km}$ from the Jakarta Bogor highway inside the RRI Cimanggis complex. Arwan describes some of the circumstances of the House as follows: The place is large and sturdy though tended to be less manicured, in the backyard lots of shrubs and unkempt trees, the front of the house is supported by several pillars of brick that gives the impression of solid, all windows are shaped like good facing the room or connecting between rooms with arch at the top and can be pushed upwards. It was mentioned by Adolf Heuken that the house was built by David J. Smith between 1775 and 1778 to replace a simple guesthouse owned by a widow from the governor in place of a simple guest house. The owner is a widow of Governor-General Peter Albertus van der Parra, who is then inherited to Smith. Armin describes the house as an old building with high art, but unfortunately less well maintained.

\section{Macro semiotic analysis}

Danesi (1999: 294) says that macro semiotic analysis is the study of how signifying orders are embedded in a particular meaning structure and how meaning is built in. Stage in macro semiotic analysis is first observation. Observation can be done by collecting data (scheme someone), collecting information from fiction texts, as well as collecting information both written and oral. The second stage is a simple analysis. After identifying marker structures and systems that influence behavior or text, a researcher must analyze how they reflect the likely trends in signifying orders. It aims to identify dimensionality aspects of the structure and system. In macro semiotic analysis, there is one element called macro signified, a sign that links sign, code, and text in culture. The third stage is synthesis, namely the stages to determine the manifestations of macro signified in verbal and non-verbal codes. In addition, this stage connected macro signified with signifying order.

\section{Research Methods}

This study uses the data corpus by using interview technique, and literature study. Questions are given in the form of an open ended question so that it is possible to collect information for research and related information that is not on the questionnaire. The literature study was also conducted to seek other information from the community about their opinions and views on the colonial building in Depok. Literature study method is used because this research is also diachronic research, so the possibility of information in the past is not widely known by the people today.

The data collection is done by using interview method. According to Mahsun (2012), this method is used to extract data from respondents. To use this skillful technique selected 4 respondents in the surrounding community who live in the colonial building area. Taking informants representing the place to be interviewed is the colonial building area in Depok, which is around the Bridge Panus, Immanuel Church, Depok China, and House Landlord Cimanggis.

The perspectives used in analyzing this research are macro semiotic analysis (Danesi \& Perron, 1999). Micro semiotic analysis consists of three stages: observation, (observing targeted individuals in a social context for obtaining the required data), analyzing the order of marking and the structure of meanings projected individually according to the context, and synthesizing.

The steps in this research are designing, determining the scope, and determining the characteristics of participants and looking for related information sourced from books, websites, and Youtube. The data will then be analyzed using a Danesi perspective (or denotation, connotation, and annotation) or three points of view in analyzing space as the object of research, namely 'territoriality', 'extension of self', and meaning or ' social connotation ', then further draw conclusions. 


\section{Discussion}

The analysis will be divided into two parts by using Peirce Tricotomy perspective and Danesi: Denotation, Connotation and Annotation. Here's the explanation.

\section{Peirce Perspective}

Based on interviews with some sources, there are generally some markings on the colonial building area:

a. The buildings tend to be dull

b. The building is different from the current building

c. For buildings such as houses, use many wood, for example windows made of wood

d. The building tends to be strong

e. The building is less manicured

f. Located in some areas of the former Netherlands such as in the youth road (Depok)

g. It has its own peculiarities that are different from today's buildings

Based on the findings of researchers on how society marks and elucidate colonial building area, generally found that people tend to mark the colonial building area by way of index. Referring to the Peirce trichotomy of representamen, objects, and interpretations then we will see the dicent-indexical-sinsign pattern. Dicent, commonly known as proposition, according to Peirce is "... is a sign of actual existence," (Noth 1995: 45) or can we say dicent as a marker whose existence is real. So if we refer to the Colonial building Area, we see there is a real material that is the building itself; Bridge panus, GPIB Immanuel Depok, China Hut, and Former Cimanggis Landlord. How then people indicate that these buildings are colonial buildings represented by indexical means. Index according to Benny Hoed (2014:9) is a sign that the relationship between representamen and object is causal or contiguous. The community marks the building as a colonial building because there are reasons such as dull buildings, wooden windows, less manicured, unique, different from others. There are certain characteristics attached to the building which indicate that it was a building in the colonial period. Next is sinsign, or according to Peirce (Noth, 1995: 44) referred to as tokens. The meaning of the building area is varied. More specifically based on the results of interviews and literacy studies, the following describes how societies give marking and meaning to the colonial building area:

Based on the results of interviews there are some characteristics that become a marker of Panus Bridge as a colonial building that is the Panus written and its year of built, the bridge model is different from the model of the present bridge (Panus Bridge II as a comparison), the road is small, crossing the Ciliwung river, has a short pillar. Referring to what is mentioned above the representamen pattern in accordance with Peirce Trichotomy is dicent indexical sinsign. In addition, the naming of the Panus bridge also belongs to the indexical because its name refers to the name of the architect who built it, Stefanus Leander. The community (in the writings of online media) interpreted the Panus Bridge as a mystical building because some of the stories of people who had passed there saw sightings, or like seeing women looking dressed again in a lonely way. But interestingly, the results of interviews with the surrounding community is different. The surrounding community thinks that the bridge is mediocre, there is no mystical element, especially after the construction of the Panus bridge II and the there is more and more housing, mystical stories are rarely heard.

Land house Land Cimanggis as described Arwan in his blog has a marker-marker as follows: The place is big and sturdy though tend to be less well maintained, in the backyard lots of shrubs and trees unkempt, the front of the house sustained some pillars of brick that gives the impression of solid, all similar shaped windows either facing the room or connecting between rooms with arch at the top and can be pushed upwards. The significance 
of Cimanggis Landlord building as a historical building is considered to be a mediocre building for the community, and some even interpret it as a mystical and haunted building, especially since the building is never inhabited.

For people in the vicinity of the colonial building area, the signs that mark the colonial building area are less important or common to them. They assume that these buildings have no specificity or uniqueness, although they realize that the building is an ancient building. Yet, it becomes important for a historian, a cultural or a tourist, because they interpret it as a historical building. This can be seen on the writings on the website/blog about colonial buildings that the buildings should be maintained and preserved even can be made as a religious and historical tourism.

Furthermore, when catching the mark, the responses given by the community were varied. For the people who are already accustomed to live around colonial buildings, these places become common, nothing is special, nothing interesting. Yet, when the place is visited by tourist and historian, they will surely has a special interest and also a sense of pleasure and pride to be able to visit colonial building area. Various sense and meaning, which involves the interpretation of the subject, called interpretant.

The next issue is how does something appear as a sign? Buildings that tend to be dull, windows mostly use wood, sturdy buildings, and less manicured buildings are a sign to us; second, we know because we study history. Based on the explanation above, we can conclude these things as a sign.

\section{Danesi Perspective}

The analysis on space is based on three variables of territoriality (denotation), self-standing (connotation) and social connotation (denotation). This research will look at the three space variables. Here's the review:

\section{a. Territoriality (Denotation)}

Based on data from the official website of West Java Provincial Government, Panus Bridge is a bridge across the Ciliwung River as well as connecting Old Depok and New Depok. Panus Bridge is a bridge connecting Old Depok with New Depok which was built in 1917 until 1918 when the VOC was still in power. Panus name taken from the name of the person who designed the architect that is Stefanus Leander. The bridge, which has a length of $100 \mathrm{~m}$ and a width of $5 \mathrm{~m}$, was used as a connecting lane up to 1990. The next building is Immanuel Depok Church. The building was built by Cornelis Chastelein in the 18th century. The next building area is the Chinese Cottage on Margonda Raya street which is a Tionghoa-Java settlement under the oldest VOC government in Indonesia. Relics that can be found here are old complex and Chinese cemetery. Furthermore, Cimanggis Landlord house which was built in 1775 - 1778 by David J. Smith with an architectural image of the Dutch buildings of the 18th century.

Discussion on territorial variables lead us to see the space is built in accordance with its main function. As Hoed points out that territoriality means we see space as an objective physical body, or in its semiotics Barthes is called denotation. So, refer to the point, we can say that the spaces in the colonial building area are basically built to fulfill certain functions. Panus Bridge is built to connect one area with other areas in order to facilitate access for the community. Immanuel Church of Depok as a place of worship of Christians. Chinese huts were built as a residence for ethnic Chinese in Depok, and the Cimanggis Landlord House was built for the residence of the Governor of the Dutch era.

\section{b. Self-Esteem (Connotation)}

Space as an extension of the self means the territory seen from the human point of view, which is seen as a human mental reality. Stages in this analysis can also be called connotation. The meanings constructed by the community about the colonial building area are focused on this section. To find out how social connotations are built, researchers see from the writings in some online media about their views and opinions about the colonial building area itself. In general, the existing meaning of the colonial buildings is that these buildings are a cultural heritage that needs to be maintained and need to be preserved because it has historical and cultural value. 


\section{c. Social Connotation (Annotation)}

Social connotation means space is seen from the point of social meaning. Stages in this analysis are also called annotations, i.e. new meaning that emerges that is different from social meaning. To find out how the annotation took place about the colonial building area, the researcher interviewed the community around the colonial building area. It aims to find out how they give meaning to the building.

Based on the interviews of the people living in the vicinity of the colonial building area, almost $80 \%$ found that the meaning of the existing buildings as a symbol of history, considered as something common. When the researchers asked whether there was anything special about the buildings, most of them answered no, either because they were used to the scene or not. While others still assume it is a bit unimportant as something of historical value.

The meanings are interesting to study, because there is a new meaning that emerged from the colonial building area is the area of colonial buildings is an area of mediocrity, nothing special. They consider the signs present around them to be less important. Here we can see there is a shift and change of meaning that previously these areas as a cultural heritage and have historical value interpreted as mediocre buildings and only inheritant of colonial relics.

\section{Conclusion}

Space as part of human life is not only understood as functional meaning only. There are certain markers that actually make it meaningful. But people's understanding are different. There are some people consider it interesting and unique, but some other consider it uninteresting.

Based on the results of the analysis, the authors conclude that there is a marking of the colonial building area that is used as a marker to identify colonial-era buildings. Through the elements of marking, the process of semiosis occurs when the community elucidates the area of the building as something of historical value as well as mystical. However, the meanings also experience a shift or there is a new meaning in society (annotation), where the buildings are only considered as building only. It does have historical and cultural value, but those values fade with time and the buildings are forgotten. This certainly needs to be our common concern (especially the government) as a responsible part in the management and development of areas of historical value.

\section{References}

[1] Christommy, Tommy. Konsep Dicent dalam Kajian Urban dan Landscape Toponimi. Seminar Nasional Semiotik, Pragmatik, dan Kebudayaan (pp. 47-54). Depok : Fakultas Ilmu Pengetahuan Budaya.

[2] Danesi, Marcel. 2011. Pesan, Tanda, dan Makna: Buku Teks Dasar Mengenai Semiotika dan Teori komunikasi. Jogjakarta: Jalasutra.

[3] Danesi, M., \& Perron, P. 1999. Analyzing Cultures. Bloomingtoon dan Indiana: Indiana University Press.

[4] Hoed, Benny. 2014. Semiotik dan Dinamika sosial Budaya. Depok: Komunitas Bambu

[5] M.S, Mahsun. 2012. Metode Penelitian Bahasa. Jakarta: Rajawali Pers.

[6] Noth, W. (1990). Handbook of Semiotiks. Brimington and Indianapolis: Indiana University Press. Internet source:

[7] http://www.disparbud.jabarprov.go.id/wisata/dest-det.php?id=583\&lang=id. Access. 29 Mei 2017.

[8] http://jakarta.panduanwisata.id/beyond-jakarta/depok/mengenal-sejarah-kota-depok-di-kawasan-bangunan-kolonial/. Access. 29 Mei 2017

[9] http://arwanamin.blogspot.co.id/2016/04/rumah-tuan-tanah-cimanggis.html. Access. 30 Mei 2017

[10] http://arwanamin.blogspot.co.id/2016/04/jembatan-panus-depok.html. Access. 30 Mei 2017

[11] http://www.kompasiana.com/iwannurdin/asal-mula-kampung-pondok-cina-depok_5500c066a333119f6f51216d. Access. 31 Mei 2017

[12] https://www.otonomi.co.id/ragam/mengulik-jejak-sejarah-etnis-tionghoa-di-pondok-cina-depok-170123k/rumah-tuapondok-cina.html. Access. 31 Mei 2017

[13] http://nasional.kompas.com/read/2017/01/26/06060021/sejarah.pondok.cina.dan.rumah.tua.yang.kehilangan.konteks.b udaya.?page=all. Access. 1 Juni 2017 